\title{
THE THEOLOGICAL VISION OF ELIZABETH A JOHNSON
}

Susan Rakoczy

St Joseph's Theological Institute University of KwaZulu-Natal

\begin{abstract}
Elizabeth Johnson is a very significant Catholic feminist theologian whose work has a world-wide influence. Analysis of the growing corpus of her work in the last twenty-five years demonstrates that she uses a very clear feminist methodology based on women's experience which is not univocal but very diverse. This methodology has three phases: Deconstruction, a search for alternative sources and reconstruction. Johnson applies this methodology to many aspects of the Christian tradition: God, Christ, Mary, the communion of saints and themes which are newer: Justice for women in the church and ecological concerns. Central to her re-working of the tradition from a feminist perspective is Sophia, or Wisdom. Her theological perspective joins theory and praxis in the call to do God's truth in justice and compassion.
\end{abstract}

Key Words: Elizabeth Johnson, Feminist Theology, Sophia

\section{Prologue}

I chose Elizabeth Johnson as my conversation partner for two reasons. Firstly, she is one of the foremost Catholic theologians in the United States and her work has a world-wide influence. Secondly, we have been friends and colleagues since our days of postgraduate study at the Catholic University of America and I have followed her theological development closely.

Which story is Elizabeth Johnson telling? She is telling the story of Sophia, of Wisdom at work and at play throughout the universe, in the history of salvation in and through Jesus-Sophia.

How does she tell the story? She narrates it through an intentional feminist lens and a clear feminist methodology. Her groundbreaking work in the understanding of God, Christology, Mariology, the communion of saints, justice for women in the church and ecological concerns demonstrates the breadth of her theological concerns which are focused on women's flourishing. This is the criterion of her interpretation of the central themes of the Christian story: Does an interpretation of a Christian teaching bring life to women or does it continue to oppress and demean them?

As a systematic theologian, Johnson uses a Trinitarian grammar focused on Sophia to reinterpret God who is Holy Mystery and Sophia's action in the world. This grammar has a structure which illuminates the whole of Christian doctrine. Sophia, named by Johnson as She Who Is, is self-giving love and empowering love to and in all of Her creation.

IntroductionElizabeth Johnson was born on December 6, 1941 in the United States. Raised in an Irish-Catholic family in Brooklyn, New York, her early education was in Catholic primary and secondary schools. In 1959 she entered the Sisters of St. Joseph of Brentwood, Long Island, a Catholic religious congregation. This was three years before the 
beginning of the Second Vatican Council (1962-1965) and she describes her religious formation as "strong-top down authority, strict daily horarium, full habit, restricted human relationships, emphasis on distance from the world and saving soul and the souls of others". 1

Her theological studies were done at Manhattan College in New York where she earned a MA in 1970 and at the Catholic University of America in Washington, DC where she earned a PhD in 1981, the first woman to receive this degree. She was on the faculty of the Catholic University of America from 1980 to 1991 and is currently Distinguished Professor of Theology at Fordham University in New York.

She has South African connections since in 1987 she lectured in Christology during the Winter School sponsored by the Archdiocese of Durban and travelled throughout the country giving a series of lectures which were later published as Consider Jesus: Waves of Renewal in Christology. ${ }^{2}$ She retains a lively interest in South African events through her friendships here.

\section{Turning to the World}

Elizabeth Johnson narrates the vocational crisis she faced in 1965 as she was preparing to make her final vows. The instructions she was receiving were world-denying, and even though the Second Vatican Council was about to enter its fourth session, it had made no impact on her religious congregation. She relates that she "kept thinking that if God created and loved this world, then shouldn't those of us radically seeking God in religious life be in the forefront of engagement with this world?"3

One day she was given the draft of a conciliar document which was to be voted on later in the year and was later titled Gaudium et Spes (joy and hope), "The Pastoral Constitution on the Church in the Modern World". She describes how she was riveted by its opening words: "The joys and the hopes, the grief and the anxieties of the people of this age, especially those who are poor or in any way afflicted, these too are the joys and hopes, the griefs and anxieties of the followers of Christ" (GS 1) and read them over and over.

What she found in the draft spoke directly to her heart: That the church and the world should be in dialogue, its analysis of the current situation in the world, its emphasis on the dignity of every human being, and the call for Christians to serve the world, not run from it.

That afternoon she realised that it 'is worth my life' for "on that hot summer afternoon my young questing spirit intersected with this document and found its life-long direction". 4 Her theological studies, the beginnings of feminist theology and her contributions as a theologian were still in the future, but the vision that she grasped that day, to be a Christian in the world, is central to her vision and work.

\section{Theological Influences}

Reflecting on the key influences in her development as a theologian she names the following:

\footnotetext{
Elizabeth A Johnson, "Worth a life A Vatican II story," in William Madges \& Michael J Daley (eds.): Vatican II: Forty personal stories (Mystic, Connecticut: Twenty-Third Publications, 2003), 202.

2 New York: Crossroad, 1991. The South African editions are Who do you Say that I am? (Hilton, South Africa: Order of Preachers, 1988) and Who do you say that I am? [with Susan Rakoczy] (Pietermaritzburg: Cluster Publications, 1997).

Johnson, "Worth a life," 202.

Johnson, "Worth a life," 204.
} 
- The documents of Vatican II, especially Gaudium et Spes;

- Biblical scholarship flourishing since the Council;

- American death of God theology;

- European Catholic theology, especially that of Rahner, Metz and Schillebeeckx;

- European Protestant theology, especially that of Bonhoeffer, Moltmann, and Pannenberg, on whom she wrote her doctoral dissertation;

- Latin American liberation theology, enhanced by its expression in the South African context;

- Feminist theology, with its diverse voices in womanist, mujerista, Asian-American, and third-world women's theologies;

- Current frontiers in inter-religious theology, ecological theology, and postmodern thought, especially as these are mediated through feminist theory. ${ }^{5}$

Her work has a strong focus on issues of suffering and healing, with a particular concern for women. She entered the professional theological world in the early 1980s when feminist theology was in its first generation ${ }^{6}$ and has been a major figure in its development in the last twenty-six years.

\section{Christology: The Historical Jesus, Women and the Wisdom Tradition}

Her first theological interest was Christology and her doctoral thesis (1981) was titled "Analogy, Doxology, and their Connection with Christology in the Thought of Wolfhart Pannenberg". After writings two articles stemming from her thesis, she began to make connections with the historical Jesus and formal Christological concerns. ${ }^{8}$ Other early articles began to explore the links between Christology and Mariology and Christology and the doctrine of God. Shannon Schrein notes the centrality of Christology in her work in three key areas: "Within her Mariology, as part of her theology of God, and as a study in itself including the closely related area of soteriology.",

She describes her work in Christology as a 'feminist liberating Christology' which has six elements: "A non-dualistic feminist anthropology, the historical Jesus, the symbol of Christ, Christological doctrine, the doctrine of God, and salvation." ${ }^{10}$ Her Christology can be described as proceeding 'from below', beginning with the human, historical Jesus.

The historical Jesus functions as a bridge between his historical existence two thousand years ago and the faith experience of Christians today:

5 Elizabeth A Johnson, "Forging theology: A conversation with colleagues," in Phyllis Zagano and Terrence W Tilley (eds.): Things new and old: Essays on the theology of Elizabeth A. Johnson (New York: The Crossroad Publishing Company, 1999), 122.

6 The seminal article by Valerie Saiving, "The human situation: A feminine view", Journal of Religion (1960) presented the contrast between men and women as moral agents and asserted that much of $20^{\text {th }}$ century theology was inadequate to women's needs. Mary Daly's two books, The Church and the second sex (New York: Harper Colophon Books, 1968, 1975) and Beyond God the Father (Boston: Beacon Press, 1973) first raised questions about the pervasive patriarchy of Christianity and the use of male language for God.

7 Catholic University of America, 1981.

8 Elizabeth A Johnson, "The ongoing Christology of Wolfhart Pannenberg," Horizons 9 (1982), 237-250 and "Resurrection and reality in the thought of Wolfhart Pannenberg," Heythrop Journal 24 (1983), 1-18; "The theological relevance of the historical Jesus: A debate and a thesis," The Thomist 48 (1984), 1-43;

9 Shannon Schrein, Quilting and braiding: The feminist Christologies of Sallie McFague and Elizabeth A. Johnson in conversation (Collegeville, Minnesota: The Liturgical Press, A Michael Glazier Book, 1998), 49.

10 Johnson, "Forging theology," 104. 
The reconstructed image of the historical Jesus not only functions today as the equivalent of the memory impression of Jesus in the early Church, but actually is the equivalent of it, i.e. is the means by which significant segments of the present generation of believers remember Jesus who is confessed as the Christ. As such, it is an element of the living tradition of the present Church. ${ }^{11}$

In Consider Jesus (1991) she argues that "as a genuinely human being, Jesus Christ is God with us" 12 and the key to understanding his humanity is his kenosis or self-emptying (Phil 2:6-7). Because the stress on Christology had been to focus on his divinity, it diminishes the humanity of Christ to say "Jesus is God, and in addition human as well."13 Rather, Christology from below states, "As this human being, Jesus is the Son of God. Precisely as this human being he is God in time. He is fully human, fully free, fully personal, and as such he is God who has self-emptied into our history."14

This emphasis on the fully human Jesus is explored in other chapters on his self-knowledge, his ministry, and his concern for justice. She is clear that both ascending and descending Christology are important; they each in different ways "bring us to the same point of intrinsic concern for social justice on this earth." 15 The book continues with reflections on Latin American liberation Christology, feminist Christology, and the problem of suffering. ${ }^{16}$

\section{A Feminist Christology}

One dimension of the humanity of the historical Jesus is his gender; he was incarnated as a male human being. This historical fact has been used throughout the Christian tradition as one of the ways to deny the full humanity of women. As Christianity gradually absorbed the cultural ethos of the Roman Empire, its structures began to reflect the patriarchy of the imperial household. The assertion that 'there is neither male nor female' (Gal 3:28) which described the earlier egalitarian community was replaced by traditional patriarchy. ${ }^{17}$

In this process of cultural assimilation "the image of Christ consequently assumed the contours of the male head of household or absolute ruler". ${ }^{18}$ The Christology which resulted is patriarchal and "values male over female reality, arranging both in a hierarchal social order and assigning the highest value and pride of place to men" and thus becomes a Christology "that functions as a sacred justification for the superiority of men over women."

Johnson is careful to assert that the maleness of Jesus is not in question; it is part of his historical particularity together with his social location, race, and Jewish religious faith. But his gender has been asserted to be constitutive of his identity in ways that limit women's flourishing as disciples. This occurs in three ways.

1 Johnson, "The theological relevance of the historical Jesus," 25.

12 Elizabeth A. Johnson, Consider Jesus: Waves of Renewal in Christology (New York: The Crossroad Publishing Company, 1991), 30.

13 Johnson, Consider Jesus, 31.

Johnson, Consider Jesus, 31.

Johnson, Consider Jesus, 78.

6 The 1997 edition of Who do you say that I am? includes a chapter on African Christology by Susan Rakoczy, added upon request of the publisher (pp 79-86).

17 Elizabeth Schüssler-Fiorenza argues that Galatians 3:28 "denied all male religious prerogatives in the Christian community based on gender roles" and "this egalitarian Christian self-understanding did away with all male privileges of religion, class and caste." See In memory of her: A feminist theological reconstruction of Christian origins (New York: Crossroad, 1983), 217-218.

18 Elizabeth A. Johnson, "Redeeming the name of Christ," in Catherine Mowry LaCugna (ed): Freeing theology: The essentials of theology in feminist perspective (San Francisco: Harper San Francisco, 1993), 118

19 Johnson, "Redeeming the name of Christ," 118. 
First, it is used "to reinforce an exclusively male image of God" ${ }^{20}$ which at times makes gender part of divinity and certainly implies that maleness is closer to divinity than is femaleness. Secondly, his maleness is used to show that God prefers maleness since Jesus is a male and thus "men are said to be more conformed to the image of Christ than are women."21 Thirdly, Johnson asserts that emphasis on the maleness of Jesus puts women's salvation in jeopardy, at least in theory. The assertion of Gregory of Nazianzus (d 390) that "what was not assumed is not cured. But whatever has been united to God is saved" (Letter 101.7) is predicated on the understanding that the Word/Wisdom of God became human. If his gender is interpreted as essential to his saving and liberating work, then women are not liberated since Jesus of Nazareth was not female.

Given the patriarchal Christology which has shaped the tradition of the Church, women may be tempted to walk away from a tradition which demeans them in every possible way. And some do, of course. But for Johnson the answer to women's dilemma lies in the retrieval of the Wisdom tradition which offers women new hope.

\section{Jesus as Sophia}

The figure of Wisdom (Sophia in Greek, Hokmah in Hebrew) who appears in both the Jewish Scriptures and the inter-testamental literature was used by the first Christians to name Jesus as the Christ. Wisdom "is a complex female figure who personifies God's presence and creative action in the world." 22 The book of Wisdom describes her "as a breath of the power of God, pure emanation of the glory of the Almighty; so nothing impure can find its way into her. For she is a reflection of the eternal light" (Wis 7:25-26).

The wisdom tradition can function as a powerful and beautiful corrective to the stress on the maleness of Jesus.

Both the insights and imagery of the wisdom tradition, when interpreted by means of a feminist hermeneutic, offers a way of speaking about Jesus the Christ that can correct the androcentric bias of traditional Christology and shape the community and its engagement with the world in an inclusive, freeing and relational manner. ${ }^{23}$

Even though the Wisdom tradition emerged from the same patriarchal perspective that shaped all the Scriptures, Johnson views it as a positive resource for women for two reasons. First, it links with the ordinary experience of people, and is not focused on celebrating God's mighty deeds in history. Secondly, "the figure of personified Wisdom offers an augmented field of female metaphors with which to interpret the saving significance and personal identity of Jesus the Christ" ${ }^{\prime 24}$ and thus removes the power of the androcentric language about Christ.

Schrein notes that Johnson's use of the Sophia tradition as applied to Jesus is dependent on the work of Elizabeth Schüssler Fiorenza who argued that "the Palestinian Jesus

20 Johnson, "Redeeming," 119.

21 Johnson, "Redeeming," 119. This was the central argument of the Vatican document Inter Insigniores ("On the Question of the Admission of Women to the Ministerial Priesthood") issued in 1976. It stated that only men can represent Christ as priests because "The same natural resemblance is required for persons as for things: when Christ's role in the Eucharist is to be expressed sacramentally, there would not be this 'natural resemblance' which must exist between Christ and his minister if the role were not taken by a man; in such a case it would be difficult to see in the minister the image of Christ. For Christ himself was and remains a man" (\#5).

22 Johnson, "Redeeming", 121.

23 Elizabeth A Johnson, "Wisdom was made flesh and pitched Her tent among us," in Maryann Stevens (ed.): Reconstructing the Christ symbol: Essays in feminist Christology (New York: Paulist Press, 1993), 96.

24 Johnson, "Redeeming," 122. 
movement understands the ministry and mission of Jesus as that of the prophet and child of Sophia sent to announce that God is the God of the poor and heavy laden, of the outcasts and those who suffer injustice." 25

Jesus Sophia is a friend to all, accessible and with the people. In her characteristic lyrical style, Johnson describes him:

Like her, he delights in being with people; joy, insight and a sure way to God are found in his company. Again and again in imaginative parables, compassionate healings, startling exorcisms, and festive meals he spells out the reality of the gracious goodness and renewing power of Sophia-God drawing near. ${ }^{26}$

The use of the Sophia tradition in reference to Jesus has the power to break the historical theological assumption that there is an ontological connection between the being of God as male and male human beings. Thus it gives hope to women disciples that they too image Christ, who, now risen and glorified, is no longer identified by the particularity of his gender.

There are also broader implications for Christian life as a whole when the Sophia tradition is affirmed and women's dignity is honoured. These relate to justice for the poor, inter-religious dialogue and ecological care for the earth, ${ }^{27}$ all of which are evident in the whole corpus of Johnson's work.

Elizabeth Johnson's initial work in Christology with its focus on the historical Jesus, the use of the Wisdom tradition, concern for gender questions and links to issues of justice and care for the earth is expanded and developed in all her subsequent work on God, Mary, holiness, and ecofeminism.

\section{She Who Is: God in Female Images}

Johnson's work on the Wisdom tradition as applied to Jesus served as the foundation for her most important work, She Who Is: The mystery of God in feminist theological discourse (1992) which won a number of prizes and awards, including the Louisville Grawemeyer Award in Religion in 1993.

Clearly and cogently she describes the methodology of feminist theology and then uses it creatively to re-image the triune God in female images. ${ }^{28}$ Feminist theology begins with women's experience which she names as "a resource seldom considered in the history of theology". ${ }^{29}$ Experience is not univocal, and she names the various dimensions that differentiate women in terms of race, class, culture and other historical aspects. White middleclass women of the West and poor women of Africa and Asia have vastly different experiences yet are united through the common and yet diverse experiences of patriarchy in religion and society.

The method of feminist theology has three movements. First is deconstruction which "unmasks the hidden dynamic of domination in the Christian tradition's language, custom, memory, history, sacred texts, ethics, symbolism, theology and ritual". ${ }^{30}$ This is followed

25 Schrein, Quilting and braiding, 60. See Elizabeth Schüssler Fiorenza, In memory of her (New York: Crossroad, 1983), 135.

26 Johnson, "Redeeming," 123; She Who Is, 157.

27 "Redeeming", 132.

28 Her article "Jesus the wisdom of God: A biblical basis for non-androcentric Christology," Ephemerides Theologicae Lovanienses 61(1985), 261-294 contains the outline of her thinking which was to be developed in She Who Is.

29 Elizabeth A Johnson, She Who Is: The mystery of God in feminist theological discourse (New York: Crossroad, 1992), 29.

30 Johnson, She Who Is, 29. 
by a search for alternative sources within the Christian tradition which will assist women in realizing their full personhood. Thirdly, feminist theology reconstructs Christian symbols and norms in order to assist women's flourishing.

Johnson quotes Rosemary Ruether's now classic description of the principle of feminist theology:

The critical principle of feminist theology is the promotion of the full humanity of women. Whatever denies, diminishes, or distorts the full humanity of women is, therefore, appraised as not redemptive ... what does promote the full humanity of women is of the Holy... 31

She names 'women's flourishing' as the criterion of judgment of the adequacy of this theological reconstruction. The goal of this new way of doing theology is the transformation of the human community which will be "a liberating community of all women and men characterized by mutuality with each other and harmony with the earth". 32

Johnson's theological project of reconstructing the doctrine of God in female images begins with her critique of the God-language of the Christian tradition. She names its deficiencies as exclusivity - the sole use of male names for God, the literal sense of male images which communicates that "maleness is an essential character of divine being" 33 and the patriarchal paradigm of a male God ruling the universe.

Since symbols penetrate deep levels of the human psyche and imagination, the "patriarchal God symbolism functions to legitimate and reinforce patriarchal social structures in family, society, and church" and "is a tool of subtle conditioning that operates to debilitate women's sense of dignity, power and self-esteem." ${ }^{34}$ She forthrightly declares that "literal patriarchal speech about God is both oppressive and idolatrous" 35 which both justifies social structures of women's oppressions and narrows the mystery of God into categories which support male power.

\section{Resources in the Tradition}

After this thorough deconstruction of male images of God, Johnson then looks to the Christian tradition for nuggets of gold and precious gems which can illuminate the mystery of God in ways which support women's flourishing. She finds three: The presence of Wisdom in the Scriptures, the understanding of God's incomprehensibility and the use of analogy.

As previously noted, Wisdom is a much-neglected image in Christology and Johnson traces Her presence in the Hebrew Scriptures and in the words and actions of Jesus as Sophia's child.

The Christian tradition's nearly exclusive use of male images for God demonstrates the lack of understanding that God is essentially unknowable, and beyond all images and concepts. She quotes Augustine of Hippo's salient warning:

If you have understood, then this is not God. If you were able to understand, then you have understood something else instead of God. If you were able to understand even partially, then you have deceived yourself with your own thoughts. ${ }^{36}$

Allied to this warning against theological omniscience is the use of analogy, a traditional

31 Rosemary Radford Ruether, Sexism and God-talk (Boston: Beacon Press, 1983), 18-19, quoted in Johnson, She Who Is, 30.

2 Johnson, She Who Is, 31.

Johnson, She Who Is, 33.

Johnson, She Who Is, 36, 38.

Johnson, She Who Is, 40.

Augustine, Sermo 52, c.1, n. 16, quoted in Johnson, She Who Is, 108. 
tool in Christian theology. Analogy "prevent(s) affirmations about God from being interpreted as direct transcripts of reality" 37 by its three-fold method of affirmation, negation and eminence. A description of God as love, for example, is true (affirmation) but since human concepts of love have nothing to do with God as love we can say that God is not loving (negation). Yet we can assert that God as love is true and far beyond all human words about love (eminence). When words and images of God are understood analogically, they open up the human heart to God as mystery, far beyond our feeble articulations.

\section{Female Images of God}

As Johnson develops her understanding of God in striking female images, focused on Sophia, she explains that feminine images of God are not sufficient because what is needed is a new re-conceptualization of God. The attempt to introduce a feminine aspect of God into the Trinity by speaking of the Holy Spirit as feminine is a deficient approach for several reasons. The first is that the first two Persons of the Trinity remain in male language, "with the male principle still dominant and sovereign." 38 Secondly, use of the feminine for the Spirit is prone to gender stereo-typing. The male Persons are described in terms of agency, order and generation, while the Spirit is associated with "receptivity, empathy, and suffering"39, which are typically associated with women across all cultures.

Instead, Johnson asserts that female imagery for God must be used for the full mystery of God. It is not sufficient to identify one 'dimension' of God (indeed, does God have dimensions?) with women. Female imagery by itself "points to God as such and has the capacity to represent God not only as nurturing, although certainly that, but as powerful, initiating, creating-redeeming-saving, and victorious over the powers of the world." 40 Since women are created in the image of God, female metaphors are as suitable as male metaphors as attempts to speak of the mystery of God.

Trinitarian theology usually begins with the first Person, the Creator and source of all being. But Johnson begins with the Spirit because in the many conversations which she had with women as she shared her theological project, they told her that their experience of God begins with the Spirit. It is in the varieties of human experience in all their richness that Spirit-Sophia mediates the divine presence.

She describes her methodology in speaking of Spirit-Sophia:

Drawing on the biblical imagery of spirit/shekinah, wisdom, and mother, which has already set language about Spirit in a certain direction, this chapter canvasses the classical heritage for understandings of the Spirit of God that cohere with women's experience of the holy and press toward renewed speech about the mystery of God. ${ }^{41}$

Spirit-Sophia vivifies, renews, empowers and graces. Using the tradition, Johnson finds Thomas Aquinas's emphasis on love fitting language in which to describe how SpiritSophia draws persons into relationship since "the images of friend, sister, mother and grandmother indicate an agenda for human life: We are loved in order to love; gifted in order to gift; and befriended in order to turn to the world as sisters and brothers in redeeming, liberating friendship." 42

\footnotetext{
Johnson, She Who Is, 113.

Johnson, She Who Is, 50.

Johnson, She Who Is, 51.

Johnson, She Who Is, 54.

Johnson, She Who Is, 133.

Johnson, She Who Is, 146.
} 
The second person of the Trinity is Jesus-Sophia and Johnson both reprises some of her earlier work and expands her understanding of his life, ministry, death and resurrection. Jesus as the prophet and child of Sophia makes God's inclusive love concrete for "in imaginative parables, compassionate healings, startling exorcisms, and festive meals he spells out the reality of the gracious goodness and renewing power of Sophia-God drawing near." As Sophia incarnate, Jesus invites all to the banquet of the fullness of life which he has made possible by his total self-gift to his Abba, Mother-Sophia.

It is in describing how God is Mother-Sophia that we see the courageous creativity of Johnson's theological reflections. She first reminds us of the principle of analogy and that images of God of either gender are not literal images. But because "God the Father has become an over-literaralized metaphor" it has so monopolized speech about God that "the equally legitimate and in some ways even more appropriate symbol of God as mother is eclipsed. $^{, 44}$

She describes the challenge that feminist theologians face in using maternal images for God. On the one hand, it critiques patriarchy's exaltation of motherhood ${ }^{45}$ which also banishes it to the private sphere of the family at home. But it also seeks to honour the gifts of motherhood in a positive way, in contrast to patriarchy's description of women as 'just a mother and housewife'.

Mother-Sophia in action mothers all of created reality, for "her creative, maternal love is the generating matrix of the universe, matter, spirit, and embodied spirit alike." ${ }^{46}$ God the Mother is compassionate to all, with her concern turned particularly to those in need. Thus she is the Mother of justice and right relationships. This justice embraces ecological concern for the flourishing of creation. Mother-Sophia is not a remote dispenser of justice but God who cares for all.

To speak of God as Mother is to utter halting words which point "to the depths of that absolute mystery, expressing God as unoriginate origin, primordial being, hidden source of all that is." ${ }^{47}$ Yet Mother-Sophia is not only transcendent and thus beyond all images; she is immanent and so close to us that in Her "that we live, and move and exist" (Acts 17:28).

The Persons of the Trinity live in eternal loving relationship (the immanent Trinity) which is shared with all of creation (the economic Trinity). Johnson brings together the separate reflections on each Person as Sophia and names God as She Who Is.

If God is not intrinsically male, if women are truly created in the image of God, if being female is an excellence, if what makes women exist as women in all difference is participation in divine being, then there is cogent reason to name toward Sophia-God, "the one who is". 48

She Who Is, God in female images, is linguistically possible, theologically legitimate, and existentially and religiously necessary. To hear the mystery of God named as She Who $I s$ is an invitation to women to "shuck off their mean estate and lay hold of their genuine

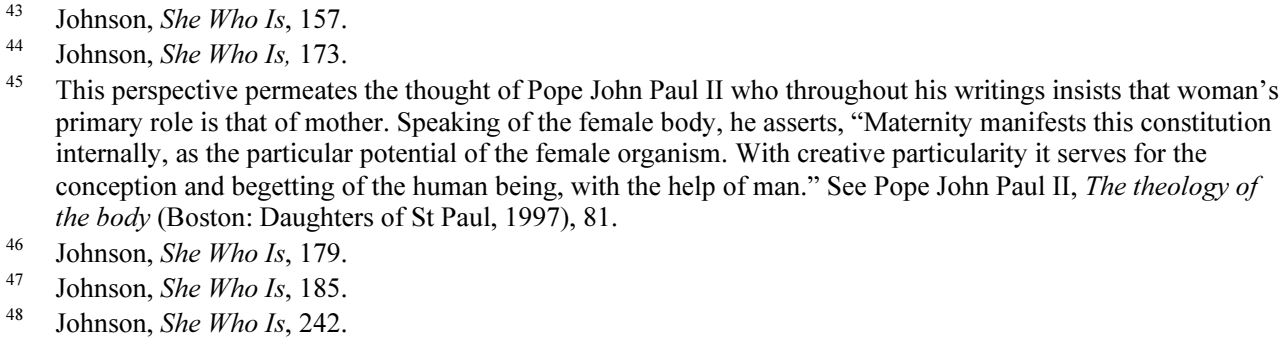


human dignity and value." ${ }^{, 49,}$ and together to do the works of Sophia which resist evil and create, nourish, vivify all persons and all of creation.

The methodology of feminist theology which Elizabeth Johnson so clearly delineates in She Who Is - deconstruction, searching for alternative resources in the Christian tradition and reconstruction of the theological symbol - is the template of all her theological work.

She has continued her reflections on God in her most recent work, Quest for the Living $G o d^{50}$ which offers all those with serious questions about God an overview of the major themes of the divine relationship with humanity and all of creation. Echoing Karl Rahner, she names God as Holy Mystery, ever greater and ever near who is the God of compassion, the liberating God of justice and right relationships who breaks the chains of poverty and racism, a Mother God, the God of the fiesta and the one God of all religions who as Creator Spirit is the vivifier of all creation.

As she concludes She Who Is, her ground-breaking theological treatise on God with the phrase 'friends of God and prophets', Johnson alerts us to the next two themes which have followed in her work, a revisioning of the communion of saints and a Mariology 'from below'.

\section{Friends of God and Prophets}

Elizabeth Johnson had long been fascinated by Mary ${ }^{51}$ but as she began work on her interprettation of Mariology, she found that it diverged into an investigation of the communion of saints. ${ }^{52}$ This resulted in Friends of God and Prophets: A Feminist Theological Reading of the Communion of Saints. ${ }^{53}$ It is here that we find her ecclesiology, named as the communion of saints, and some reflections on eschatology.

She discovered that "the communion of saints is one of the least developed symbols in the history of theological explanation. ${ }^{54}$ Within the Catholic tradition, saints have been honoured from the first centuries of Christian life and there are innumerable works on holiness and sanctity. But Johnson's use of this symbol as a root metaphor for the church is new and very creative for she recognizes that "the traditional construal of the communion of saints fails to connect with contemporary experience on deep cultural, psychological, and spiritual levels." ${ }^{, 55}$

From a feminist perspective, the meaning of holiness has been interpreted by men down the centuries and women's voices and stories of how they lived the Christian life have often been muted. Male saints dominate the Roman Catholic calendar of saints and Johnson

49 Johnson, She Who Is, 244.

50 London and New York: Continuum, 2007.

51 Her first article on Mary was "Mary and contemporary Christology: Rahner and Schillebeeckx," Eglise et Théologie 15 (1984), 155-182. Other articles such as "The Marian tradition and the reality of women," Horizons 12 (1985), 116-135 and "The symbolic character of theological statements about Mary," Journal of Ecumenical Studies 22 (1985), 312-335 contain the seeds of the Mariology developed in Truly our sister: A theology of Mary in the communion of saints (New York and London: Continuum, 2003).

52 In the introduction to Friends of God and Prophets she states, "Working with the communion of saints into a hermeneutical key for a feminist interpretation of Mary grew into dozens of pages and then multiple chapters ... the result is the present volume on the doctrinal symbol of the communion of saints alone, and a projected companion volume in which Mary will be interpreted in its light" (Ottawa: Novalis and New York: The Continuum Publishing Company, 1998, 1).

53 Ottawa: Novalis and New York: The Continuum Publishing Company, 1998.

54 Johnson, Friends of God, 9.

55 Johnson, Friends of God, 23. 
points out that in the first eight decades of the $20^{\text {th }}$ century $75 \%$ of the canonized saints were male and $25 \%$ were female. ${ }^{56}$

Men have interpreted women's struggles and sufferings, achievements and greatness through the lens of patriarchy. Frequently the stories of women saints have come to us through their male biographers, as in Raymond of Capua's biography of St Catherine of Siena for he was her spiritual director. This distortion is evident in many ways:

Acts of radical discipleship are transmuted into obedience to the male hierarchy; women's sufferings in the struggle for their own religious identity are veiled as a proper asceticism; stereotypical feminine virtues are promoted in place of raw courage in the Spirit. ${ }^{57}$

The gap between ourselves and those whom the Church names as 'holy' is especially striking for married women since they seldom see the names of wives and mothers in the liturgical calendar. And even when they do appear, often the woman has ended her life in a monastery after her husband died, not at home surrounded by her children and grandchildren. This pattern is seen in the lives of women such as St Hedwig (1174-1243) and St Frances of Rome (1384-1440).

Johnson argues that this distance is a hierarchically ordering of relationships in which we approach the holy ones as humble petitioners, asking for their prayers. While she does not deny that praying for one another is important, what is more crucial is to realize that "the system of sainthood is so designed that relationships pivot on inequality while solidarity is undermined." ${ }^{, 58}$ Thus she maintains that...

Women's history of holiness has been neither remembered nor truthfully told; nor does relationship with the saints in heaven generally redound to the empowerment of the saints on earth in their struggle for human and religious dignity. ${ }^{59}$

\section{Sophia Shaping the Communion of Saints}

Once again Elizabeth Johnson finds the figure of Holy Wisdom as the most appropriate hermeneutical light to illumine the meaning of holiness. It is She who "renews all things; and in every generation she passes into holy souls and makes them friends of God and prophets" (Wis 7:27). She creates friends who are joined in relationships of love and compassion, sisters and brothers of the one God whose Spirit dwells in each of them. And they are also prophets "who are moved to speak truth to power about injustice, thus creating possibilities of resistance and resurrection." ${ }^{, 60}$

The image of the communion of saints is rooted in the experience of being a people saved and liberated through the death and resurrection of Jesus the Christ. Christians form a koinonia, one communion through baptism and the Eucharist. All share the life of God since "we were all given the same Spirit to drink" (1 Cor 12:14) and thus all are called to holiness.

Paul's use of the term 'the saints' (used sixty times in his letters) describes the depth experience of the community which shares in the holiness of God and communicates that holiness through their corporate life and their witness beyond the community. This term designates a specific corporate experience since "an individual may be regarded as a saint or holy one, but only in virtue of belonging to the community.",61

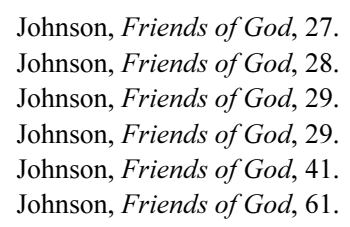


To be friends of God is to be friends with each other in community. The circle of belonging embraces both the dead and the living who share the friendship of God. Those who have gone before us, our ancestors in the faith, "surround the living church with witness to God, with lessons of encouragement, and with inspiration to hope."62

Johnson traces the historical development of the interpretation of holiness which began in the third century which changed the image of the saints from friends of God into petitioners before God. When the Christian community became the established religion of the Empire, it was engaged in fierce theological debate about the central beliefs of the faith. In addition, the ascetic movement created a two-tier community of those devoted to the ascetic ideal in the desert and early monastic life and those who did not. Gradually the Pauline interpretation of 'the saints', the holy community, was supplanted by individual 'saints' as "sponsors who could plead one's cause before the throne of God and even dispense favors in their own right." 63

Johnson argues for a restoration of the original sense of 'saints', one which undergirds the teaching of the Second Vatican Council "that all Christians in any state or walk of life are called to the fullness of Christian life and to the perfection of love" (Lumen Gentium 40). An ecclesiology which is shaped by the image of the 'communion of saints' offers distinct advantages to any hierarchical notions of sanctity and authority in the church. This ecclesiology focuses on the unity of community; it draws in every believer in her or his ordinary life; it embraces the 'cloud of witnesses' who have gone before us, those known to us (family, friends, those named in the liturgical calendar as holy ones) and those known now only by God.

It honours paradigmatic figures who speak to the Christian imagination down the ages from Augustine of Hippo of the $5^{\text {th }}$ century to Teresa of Avila in the $16^{\text {th }}$, and to friends of the more recent past such as Oscar Romero of El Salvador and Blessed Teresa of Calcutta. The final dimension of the 'communion of saints' goes beyond the anthropological interpretation to "include other living creatures, ecosystems, and the whole natural world itself" ${ }^{64}$ It is linked with the Pauline vision of all creation in Christ (Col 1:15-16) which was so beautifully developed in the works of Pierre Teilhard de Chardin SJ, a $20^{\text {th }}$ century friend of God and prophet who died in $1955 .{ }^{65}$

Johnson discusses the Protestant critique of the saints and its origins in the late medieval practices of intercession of the saints. The reformers - Luther, Calvin and others - rejected any human mediator since this detracted from the one mediator, Jesus Christ. But she points out that "the reformers had a theological vision in which there was room to honor the saints in heaven" through the use of the 'communion of saints' which they interpreted 'to mean the church itself. ${ }^{, 66}$ What is most significant in this perspective of saints is the power of their witness to us, the living, still on earth. They are not intercessors but they are our friends. Johnson thus builds a useful ecumenical bridge to join Catholic and Protestant understandings of the communion of saints by emphasizing the solidarity of the holy ones with their sisters and brothers on earth.

The feminist retrieval dimension of the 'communion of saints' is demonstrated by

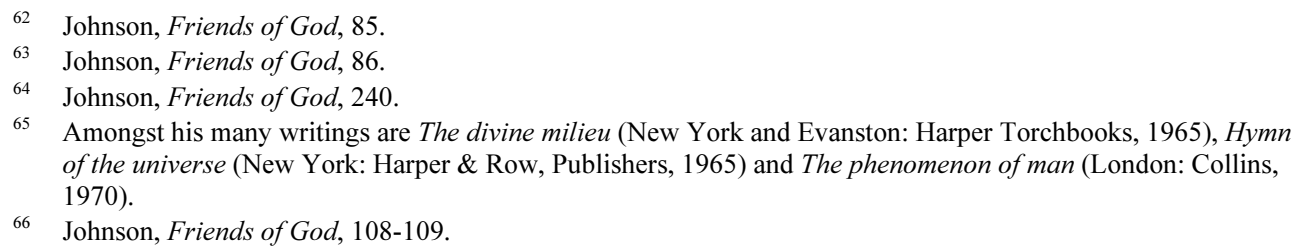


Johnson's reinterpretation of the memories of women such as Hagar, Mary Magdalene, and the virgin martyrs of the early centuries whose martyrdoms were also a form of social protest against the demands of the Roman Empire that they bear children. She includes the millions upon millions of anonymous women whose lives are now known only to God, especially those who have experienced the violence of war, rape, and domestic abuse. She laments that "a trail of bloody and violated bodies runs through the communion of saints." The anonymous include all those women whose intellectual contributions have been erased by the power of men who determine what is remembered and what is not. Remembering these women is a powerfully subversive act since it assists women today to resist all forms of the denial of the goodness of their selves and the importance of their contributions to the human community, including the church. This "feminist act of remembering in the church $\ldots$ is one living instance of how memory of the saints can serve a new justice." $" 68$

The 'already and not yet' character of the communion of saints that binds the living with those who have passed into the fullness of life becomes the foundation of her eschatological reflections. She gracefully weaves together reflections on death, hope, heaven, purgatory and hell in order to explore the question of relationships within the communion of saints after the death of those who have lived amongst us. Various interpretations of eternal life which are dualistic, positing a soul-body relationship in which the soul is 'saved' while the body decays, are rejected because they do not give justice to the profoundly relational character of human life.

Thus the question of the nature of eternal life shifts from "how an individual selfconsciousness can be preserved apart from its physical embodiment, to the question of how death transposes the relational structure of the person into a new form of communion with God." ${ }^{69}$ The saints, friends of God and prophets in justice and love, experience the fullness of the life of the Spirit which animates us all.

Johnson's creative insights into a neglected article of the creed - "I believe in the communion of saints" - are a new and profound ecclesial understanding of the relationships which bind believers on earth and beyond death. It also provides the foundation for her Mariology which begins with the human Mary, a Jewish woman living in Galilee in the first century.

\section{Truly Our Sister: Mary in the Communion of Saints}

Elizabeth Johnson returned to her work on Mary and the book which resulted, Truly our Sister: A Theology of Mary in the Communion of Saints ${ }^{70}$ is a courageous and creative presentation of a Mariology 'from below', one which presents the woman of Nazareth in solidarity with her sisters and brothers. She states that "While it draws on the history of Marian doctrine and devotion ... this is not a work of doctrinal theology in the strict sense." 71 Thus Marian dogmas such as the Immaculate Conception and the Assumption are not investigated since Johnson's intention is elsewhere. She does discuss the virginity of Mary in reference to the ways it has divided women.

She applies her now familiar method of deconstruction of the tradition, looking for new resources in the Christian tradition and then reconstructing the theological symbol or theme

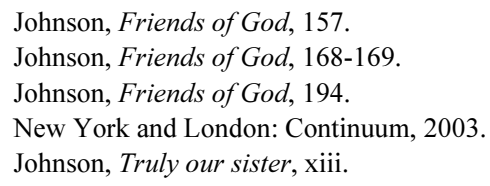


in relation to Mary. The result is a fresh portrait of Mary which crosses ecumenical boundaries and theological barriers as she "envisions her as a concrete woman of our history who walked with the Spirit."72

Mary is an ambiguous symbol for women since "the Marian tradition has functioned negatively to promote an idealized notion of the ideal female self" and yet "the living remembrance of this woman can function positively to inspire the struggle for God's compassionate and liberating justice."73

Johnson proceeds in various steps to redefine Mary and her relationship to her sisters and brothers. The first is to reprise the Mary defined by the Christian tradition and to evaluate these interpretations. On the one hand, Mary has been the only female figure close enough to God, named as Mother of God (Theotokos as the Council of Ephesus defined her in 431) to function in Christian piety. But Mary has been under patriarchal control by men who shaped and defined Marian identity since "women were not consulted, nor were they permitted to bring their knowledge of their own lives before God into this official portrait.",

Patriarchal interpretation of Mary is "saturated with sexual construals of gender" as men constructed a portrait of Mary as "the ideal female person.", 75 This interpretation has three dimensions which, while intending to exalt Mary, also demean all other women.

The first is to idealize Mary as "alone of all her sex", as both virgin and mother - an impossibility for all other women. Mary is the new Eve, rectifying by her obedience the sin of the first Eve. Since no other woman is as holy and obedient as Mary, they are ranked with Eve, the mother of sin

Secondly, Mary as the ideal female model for women presents them with the virtues that they are to emulate. This is based on "a strong gender dualism that assumes, contrary to Christian faith, that Mary models the ideal spiritual path for women while leaving Jesus for the men." ${ }^{, 76}$ Mary is the ideal handmaid, the pure virgin, the loving mother. Motherhood is seen as the raison d'etre of a woman's life, since her body is physically formed for pregnancy and childbirth. Johnson points out that a woman's identity is not exhausted by childbearing and "that there are more facets to her person as a mature woman." 77

Thirdly, the Marian tradition has functioned sociologically to divide women from each other. Based on the ascetic and monastic tradition dating from the second century, virginity has been valued more than motherhood. Thus it has been asserted that virgins are closer to God than their married sisters. This dimension of the Marian tradition establishes a hierarchy of women. When Mary is seen as a model of the church, the patriarchal description of her obedience and passivity are seen as the normative role for women who quietly and privately are to support male ecclesial leadership.

Johnson argues that the "traditional image of Mary emerges from feminist analysis as a male-designed creation that functions to define and control women.,"78

Her theological intention is radically different: "To explore the option to consider Mary as a genuine human being who acted according to the call of the Spirit in the particular circumstances of her own history."

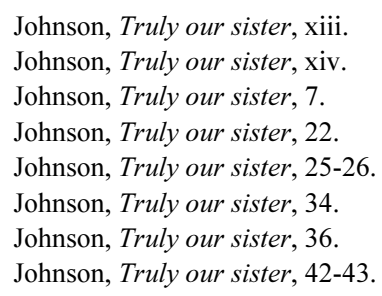




\section{Roads not Taken}

In Johnson's perspective, two theological interpretations of Mary are deficient and thus she rejects them as possible foundations for her own Mariology. The first is to identify Mary as the ideal face of woman. This image flows from the dualistic anthropology which has infected the Christian tradition since the patristic age. In this "theoretical world of gender dualism, women do not appear as historical agents in their own right but as rhetorical codes for many other concerns" ${ }^{80}$ This dualism functions to describe men and women in rigid psychological and spiritual frameworks which are then the basis for separate social roles.

Johnson describes how male theologians such as Leonardo Boff and Hans Urs von Balthasar, together with Pope John Paul II (whose Mariology is heavily influenced by von Balthasar) use this perspective to relegate women - and Mary - into the private sphere of the home. This results in women's continued marginalization in the church. This is evident in Vatican II's designation of Mary as the "model of the Church in the manner of faith, charity and perfect union with Christ" (Lumen Gentium 63). She points out that Mary is certainly not the model of the institutional church and its exercise of leadership.

This road is a cul-de-sac for Johnson since its patriarchal interpretation of Mary both elevates her on a pedestal - beyond the reach of all women and men - and insists that her life is a model for women who belong to the private sphere of life. This perspective says that since Mary was not a leader, neither are women.

The second wrong turn is to assert that Mary is the maternal face of God. Because many images of God are cold and impersonal - king, almighty lord, transcendent being - it is argued that Mary represents another 'side' of God - divine love and compassion. There is an intuitive sense that the male images of God need to be balanced by the feminine person of Mary.

Johnson critiques this road by pointing out that God is neither masculine nor feminine but is uncomplicated. All language limps and is inadequate before Holy Mystery. It is not helpful to assign the attributes of love and compassion to Mary and retain male images of God which project domination and distance. She asserts that "it makes no lasting sense to use Mary as a cover-up for defective notions of God. Rather, this female imagery should be allowed to travel back to its sources and begin to fertilize the church's imagination and piety in relation to the mystery of God." ${ }^{\prime 81}$ She stresses that is God who is Mother of Mercy, compassion, divine power and might.

For Johnson, Mary is herself. She is dissatisfied with naming Mary as the ideal or perfect disciple since this image once again distances her from all women and men. No person is perfect and when Mary is placed on a pedestal she becomes an unreachable ideal. This idealization also robs Mary of her identity as a Jewish woman and separates her from her real social context of first century Palestine living under the colonial rule of Rome.

Beth Johnson summarises her Mariology as she describes the real Mary:

First and foremost Mary is not a model, a type, an archetype, a prototype, an icon, a representative figure, a theological ideal, an ideological cipher, a metaphor, a utopian principle, a feminine principle, a feminine essence, the image of the eternal feminine, an ideal disciple, ideal woman, ideal mother, a myth, a persona, a corporate personality, an every-woman, a cultural artifact, a literary device, a motif, an example, a paradigm, a sign, or in any other way a religious symbol. ${ }^{82}$

\footnotetext{
Johnson, Truly our sister, 49.

Johnson, Truly our sister, 86.

Johnson, Truly our sister, 100-101.
} 
Rather, she is "first and foremost herself" ${ }^{83}$, a woman who had to live her own life in a context radically different from ours in the twenty-first century. She was a woman of faith but our theological interpretations of her life and meaning must be anchored in her historical reality, not in flights of the religious imagination (e.g. naming her Tower of Ivory or House of Gold in traditional prayers to Mary) or in any way diminishing her real humanity.

In this time of growing ecumenical interest in Mary, Johnson's 'Mariology from below' invites people of faith to lay aside their fears of the Mary enshrined in dogma and to meet a woman who lived her life in situations of profound challenge including the death of her son, and who is not our model or exemplar but our sister in faith.

\section{Ecofeminist Reflections}

Elizabeth Johnson's interest in ecological questions and ecofeminism dates back to the early 1990s. Her 1993 Madeleva Lecture in Spirituality ${ }^{84}$ 'Women, Earth and Creator Spirit $^{85}$ and her 1996 Presidential address to the Catholic Theological Society of America, 'Turn to the Heavens and the Earth: Retrieval of the Cosmos in Theology', both demonstrate her now familiar use of a feminist theological method which eschews dualistic and patriarchal interpretations of theological themes and brings to light new and inclusive ways to speak of the nature, human beings, and God.

In Western theological thought, this triad of relationships - human beings to the earth, among each other, and to God - "have been conceived primarily according to the values of patriarchy." ${ }^{86}$ Johnson critiques this traditional understanding which has led to the ecological crisis of our times (so much more severe now in 2007 than it was fourteen years ago) and uses the Wisdom tradition in order to construct a new form of understanding the radical connections which bind all three together. This turning to the 'circle of the earth' is not a trendy option but is the "most basic one of all. If there be no more living earth, what else is possible?",87

The hierarchical dualism which has infected Christian thought from its earliest years is now leading humanity to the brink of ecological disaster. In this ideology, there are gradations of the image of God: "Man alone bears the fullness of the image of God, while women only deficiently so, and nature not at all.",88

Not only is Christian anthropology deficient, but the neglect of pneumatology in the Western tradition has also had severe negative effects in both theology and spirituality. To forget the Spirit is to forget "the mystery of God's personal engagement with the world in its history of love and disaster... (and) the mystery of God vivifying the world, closer to us than we are to ourselves." 89

However, Johnson warns that it is not helpful is to emphasize the feminine dimension of

83 Johnson, Truly our sister, 101.

84 Sister Madaleva Wolff CSC was the president of St Mary's College in Notre Dame, Indiana in the United States. In the early 1940s she began a School of Sacred Theology in which women could earn post-graduate degrees in theology. This was the first time this was possible in the history of the Catholic Church. The Madeleva Lectures began in 1985 to honour her memory and achievements. Each year a women theologian delivers a lecture. These have all been published by Paulist Press.

85 This lecture was published as book of the same name by Paulist Press (New York) in 1993.

86 Elizabeth A Johnson, Women, earth and creator spirit (New York: Paulist Press, 1993), 3.

87 Johnson, Women, earth and creator spirit, 4.

88 Johnson, Women, earth and creator spirit, 18.

89 Johnson, Women, earth and creator spirit, 20. 
the polarity since that reinforces the dualism. Women are not closer to the earth than men are; both women and men are rational body-persons. What is needed is a radically new unifying vision of humanity, God and creation.

This she finds in the Wisdom tradition which does use female images of God to speak of the divine creative power which binds together all of creation. This is the Spirit who fills the world (Wis 1:7). This inclusive vision "dismantles the theological dualism that sets God apart from the universe... (for) ... we are all woven into the fabric of the one cosmic community." $" 90$

This pneumatology functions in three ecologically important ways. First, the Spirit grounds and sustains the cosmos as it continues to expand and grow; Spirit-Sophia "works cooperatively in and through created action, random, ordered or free." ${ }^{91}$ Secondly, SpiritSophia is divine compassion for the world and thus vivifies human beings with that same compassion to care for all those in need, including our suffering earth. Thirdly, SpiritSophia dismantles the dualism which has set humans and the cosmos at odds with each other and teaches us that all creation is sacred; everything that exists from the smallest subatomic particle to the furthest star is connected in the one Spirit of love and unity.

Thus when Johnson considers the ways that humanity has related to the earth, she decisively rejects both kingship and stewardship. Kingship is hierarchical patriarchal dualism writ large over all of creation. Stewardship at first view appears to be more friendly to creation, but it too is based on a hierarchy of care for that which is lower than human beings. She states, "In this model humanity is still at the top of the pyramid of being but has a duty to protect and preserve what seems weaker and more vulnerable."92

She asserts that only the kinship model provides the basis for care of the earth that is non-dominating and dualistic. Human beings are part of creation, not its royal apex nor its dutiful steward. All of creation is mutually inter-connected and we flourish or die together. The extinction of even one small insect species in the Amazon basin affects all of the rest of creation since the earth's flourishing has now been diminished.

These theological reflections on the cosmos, humanity and God carry the challenge of moral integrity. The ongoing destruction of the ecosystems of the earth - the only home humanity and all of creation has - through rampant consumerism, greed, increasing population growth, and a blindness to the effects of these forms of selfishness "bear the marks of deep sinfulness" which she names as 'ecocide, biocide, genocide'. ${ }^{33}$ The exploitation of the earth and injustice towards human beings, especially the poor, who are predominantly women and children, are twin realities.

Johnson issues a call to theologians and all persons of the earth to conversion - from an anthropocentric view of creation to one of compassionate solidarity with all of creation. This conversion demands repentance for ecological sins large and small and a radically new vision of the interdependence of all creation, together with a commitment to change patterns of ecological selfishness.

She insists that Christian theology must be radically refashioned so that cosmology is at its heart and all theological topics are to be reinterpreted in the light of the intrinsic connections of all that exists. To accept this mammoth challenge "sets theology off on a

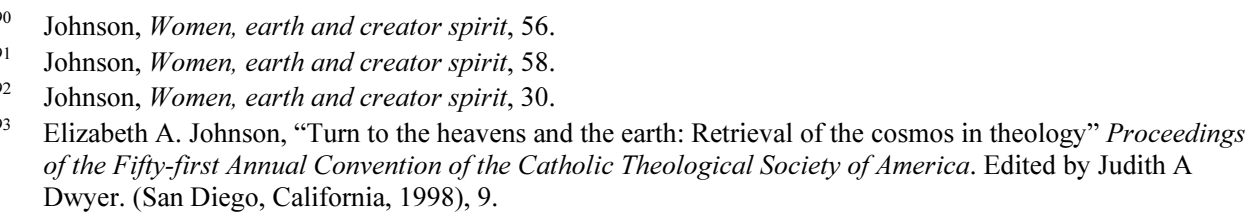


great theological adventure, one where both wisdom and prophecy will intertwine on the way to a new theological synthesis and praxis." 94

\section{Interpretation and Conclusion}

The theological work of Elizabeth Johnson which now spans over twenty years has established her as a theological pioneer in major theological areas. Her interpretation of God in female images in She Who Is will stand a benchmark in feminist theology for a long time to come. Her work on the interlocking themes of Mariology and the communion of saints is fresh and creative. Her book Truly our Sister on Mary is the finest contemporary Mariology in Catholic theology.

Her theological style is clear, eloquent and often lyrical; she knows the theological resources of the past and present and is able to present her insights in often beautiful and striking images.

She established her feminist theological methodology clearly in She Who Is and has used it consistently in all her subsequent work. This method is one of deconstruction of theological interpretations which are harmful to women and human flourishing, searching the tradition for images which are 'good news' to women, and the use of these new resources to reconstruct theological symbols in creative ways.

In this methodology the person of Sophia, God in female image, appears frequently as one of the neglected and now restored resources in the Christian theological tradition. Johnson has found in Sophia the hermeneutical key which opens up the tradition in ways which both reveal what has been neglected in the tradition and assists persons of faith to appropriate the tradition in ways which nourish their search for God.

Roger Haight has raised questions about Johnson's use of Wisdom and whether she has 'reified' this concept. He states:

In a certain sense, Elizabeth Johnson does all that she does with Wisdom in a way that parallels what the tradition did with Logos ... just as, somewhere in the tradition Logos ceased to be symbolic figurative language and was reified, so too it appears that in Johnson's system Wisdom develops an ontologically distinct referent; it is reified. $^{95}$

Johnson responds in the negative to Haight's critique. She states that at times she does "paraphrase classical manners of speaking about Christ in order to show that the female metaphor works as well, and genetically even better, than the male metaphor." 96 This is where she suspects Haight sees reification. Her purpose is larger:

But using this complex female image opens up new possibilities of language much less susceptible to reification than the Logos or Son symbols, which are so easily meshed with the maleness of Jesus. ${ }^{97}$

Elizabeth Johnson is a theologian whose feet are firmly anchored in the reality of the injustice, poverty, oppression and ecological degradation of the $21^{\text {st }}$ century. She has only to glance out of her office at Fordham University in the Bronx in New York to see the suffering of her neighbours. Thus we find a constant insistence in her writings that our

94 Johnson, "Turn to the heavens and the earth," 14.

95 Roger Haight, "Jesus Christ in the work of Elizabeth A. Johnson," in Phyllis Zagano and Terrence W Tilley (eds): Things new and old: Essays on the theology of Elizabeth A. Johnson (New York: The Crossroad Publishing Company, 1999), 55, 56.

96 Johnson, "Forging theology," 109-110.

97 Johnson, "Forging theology," 110. 
interpretations of Christian theological symbols must serve the cause of human and planetary flourishing. The God whom she so eloquently describes is a God of compassion who comes near to the suffering and calls believers to do the same.

Thus theory and praxis are joined in her growing theological corpus in myriad practical ways which challenge both professional theologians and the general reader to commitment to She Who Is and to do Her Truth in justice and compassion. 